\title{
"DEBUNKING" AND THE SHORT STORY: COOVER'S CHALLENGE TO AUTHORITIES IN "THE BROTHER"
}

\author{
Kari Meyers Skredsvig
}

\begin{abstract}
RESUMEN
En este trabajo se discuten las maneras en que el autor de "The Brother", Robert Coover, se apodera de la forma del cuento con el fin de retar las convenciones teóricas y críticas del género, además de las expectativas y las suposiciones de los lectores en el proceso de construcción de significado.
\end{abstract}

\begin{abstract}
The following discussion examines the ways in which Robert Coover appropriates the short story form in "The Brother" to challenge not only theoretical and critical conventions of that genre, but also readers' expectations and assumptions in the process of constructing meaning.
\end{abstract}

The inherent complexity of the term "short story" is a source of frustration for some critics and readers, of fecundity for others. For Robert Coover, it appears to mark a space propitious to both experimentation and redefinition. The recent surge in short story theory has provoked a myriad of questions - some of which are disguised as "answers"- testifying to the richness of this genre while contributing to establishing if not limits, at least parameters for discussion. Major issues under debate include conventional issues of definition, characterization, and evaluation, as well as more contemporary examination of story processing, discourse, and intertextuality. As Austin Wright has clarified in his essay "On Defining the Short Story: The Genre Question," choices revolving around defining the short story as a body of works, as opposed to defining it as a group of characteristics, have a radical effect on determining both the nature and the history of the short story genre, if indeed such an entity exists. He poses a telling question: are we attempting to define a concept or a category? In either case, issues of story types (differentiated by content, form, and effect), not to mention the unavoidable, unsolvable debate over length, ensure that literary discussions on the short story will be as durable, multifaceted, and lively as the form itself. For the one trait about which there appears to be a consensus is precisely the flexibility (which over time manifests a core of resilience) of the short story, made evident by its rapid evolution, enduring popularity, and present diversity. 
Most critics, following in Poe's literary footsteps consciously or otherwise, agree that the impact of the short story is directly related to its length, regardless of its content. In comparing the novel and the short story in terms of contending boxers, Julio Cortazar once stated that "the novel would win by points and the short story by a knockout" (qtd. in Rohrberger 1989: 44). This perception of the significance of length prevails in literary discussions, to the point where it is tempting to establish a sort of "duration quotient" in which poetry is conceived as "most metaphoric" because it is "most condensed" (in its length, number of words, and therefore-according to common belief-meaning), followed by short story and novel, with drama somewhere in between the two. This gives rise to intriguing considerations common to "reader-response" theory and criticism: how are a reader's expectations formed, what part do they play in story processing, how crucial is plot (especially closure) in constructing meaning in short stories, and what is (should be?) the role of story conventions. At the center of these concerns is the question of meaning: how is meaning produced? Answers to that question tend to stress the complexity of the process of constructing meaning, a complexity literary critics have often related to (or even designated as) intertextuality. The following discussion analyzes the significance of intertextuality in Robert Coover's "The Brother" in terms of its "debunking" effect on the construction of meaning in this story.

According to Thomas Leitch, the short story in United States literature has always been characterized by its "debunking rhythm," that is, its challenge to the initial assumptions of the story. Building on John Gerlach's definition of antithesis as "the movement from one belief or situation to its opposite," Leitch asserts that the debunking story is a subset of the antithetical story; as such, this type of story constitutes "not a form of knowledge but a challenge to knowledge, that is, a way of debunking assumptions...a means of unknowing rather than a means to knowledge" (Leitch 1989: 133). He is careful to clarify, however, that the displacement of the assumptions of the exposition "does not correspond to a movement from ignorance to knowledge but simply indicates a debunking or unknowing of the illusions that the story began by encouraging...without substituting any positive or more comprehensive wisdom". The debunking nature of these stories is found precisely in their questioning, rather than in any "answering." This questioning is germane to the contemporary concept of intertextuality in that it assumes, in its turn, an irreducible plurality in the text, reinforced by its refusal to provide an (much less "the definitive") answer of its own.

Textual plurality is a fundamental assumption of poststructuralist theories. Building upon Bakhtin's concept of intertextuality, Julia Kristeva contends that "each word (text) is an intersection of word (texts) where at least one other word (text) can be read....[A]ny text is the absorption and transformation of another"(Kristeva 1986: 37). Barthes asserts "[t]he plural[ity] of the text depends...not on the ambiguity of its contents but on what might be called the stereographic plurality of its weave of signifiers..."(Barthes 1977: 159). Another contemporary semiotician, Robert Scholes, incorporates these ideas into his discussion entitled Protocols of Reading by suggesting that reading is inevitably an intertextual activity, "always the connecting of signs in one text to other signs altogether" (11). According to Scholes, reading is a dynamic process which is simultaneously individual and contextual: 
(...) the activity of reading is really a matter of working through signs and texts in order to comprehend more fully and powerfully not only whatever may be presented therein but also our own situations, both in their particularity and historicity and in their more durable and inevitable dimensions. (Scholes 1989: 18)

In this aspect, Scholes concurs with Barthes' assertion that "reading is: rewriting the text of the work within the text of our lives" (qtd. in Scholes 1989: 10). Both support the present premise under consideration: the systemic intertextuality of the reading process constitutes an irreducible richness in constructing textual meaning while paradoxically "debunking" or undermining the very goal of that process. In other words, the same potential which provides the material for construing meaning simultaneously renders impossible any "final comprehension." With Coover's story, the readers are required to draw consciously upon that intertextuality to "make sense" of story at the same time that, in so doing, they deconstruct the very assumptions which serve as a foundation for that comprehension.

Coover challenges the readers of "The Brother" by questioning both form and content in this story. The title draws the reader into the narrative in an apparently transparent manner, but even the title is beseiged by multiple questions by the time the story "ends." Which brother is "the" brother? Is "brother" being used literally, as a term to denote sibling relationship, or metaphorically, in a religious or social sense suggesting a significant abstract kinship or similarity? The very simplicity of the title is immediately called into question by the format of the tale which follows; it is the first and last time that standard rules of capitalization are used. Thus, the "beginning" of the story is a beginning only in the most superficial sense of the stream of words starting at this point, just as the "end" is nothing more than the last word which appears in print on the page. By confronting the reader with this immediate challenge to expectations of format, Coover sets the reader up to face even more significant challenges to meaning yet to come. In a manner as intriguing as it is appropriate, Coover exploits both format and content in plunging into intertextual aspects which concomitantly construct and "debunk" meaning in "The Brother."

As Stanley Fish, Hans Robert Jauss, Jonathan Culler, Wolfgang Iser and other readeroriented theorists and critics have emphasized, readers approach a short story, as they do every other text, with a myriad of expectations and preconceived ideas. Certainly the conventions of the short story are uppermost in the academic reader's mind upon initiating a reading. For example, we expect a title to provide a key clue or indicate a significant focus of the story which follows. We expect some level of cohesion and coherency in the narration of the story. We expect a format of indented paragraphs made up of sentences which follow standard rules of punctuation and capitalization, at least in their bulk. We expect to be able to "make sense" of what we read. Our expectations tend to be unconscious and remain so as long as they are essentially met. However, Coover defies those expectations immediately after the title by beginning his narrative as follows:

(... ) right there right there in the middle of the damn field he says he wants to put that thing together him and his buggy ideas and so me I says "how the hell you gonna get it down to the water?" but he just focuses me out sweepin the blue his eyes rollin like they do when he gets het on some new lunatic notion (...) (636) 
Interestingly, although there is no real break between sentences and the use of capital letters is also anarchic, Coover does use punctuation marks when "quoting" exact statements, thus providing a loose format which guides the reader in structuring and "chunking" the reading, to use Lohafer's term. In "Discourse Analysis and the Short Story," Suzanne Hunter Brown discusses ways in which readers process what they read in order to "make sense" of it. When the our initial expectations are not met, the tendency is toward reformulating or substituting frames which will permit us to relate what we read to existent mental schema. Thus, for example, when our expectations of format and mechanics are not met in Coover's story, we promptly shift mental gears to make allowances for the differences. For example, we may immediately label the format "experimental" or "avant garde," which permits us to continue reading it as a short story while putting formalistic assumptions on hold. Or, being trained in formalistic considerations of narrative perspectives, we may focus on the fact that it is a first-person narration, which also allows us to obviate unspoken requirements of "standard English," both mechanical and lexical. It is unlikely that we would desist in our reading of the story because of its unusual format; if we initiate the reading on the premise that the text is a short story, we are much more likely to find or improvise ways which permit us to continue reading it as such. One major effect of this introductory clash between expectations and reality, however, is that we are more inclined to perceive and accept other confrontations in the story.

Perhaps the most obvious strategy U.S. readers are inclined to employ in searching for a mental frame to "understand" Coover's story is to call upon the Biblical intertext. For very early in the story it becomes not only "clear" but nearly impossible to ignore the strong correlations between basic elements of Coover's tale and the tale of Noah and the Ark, as told in Genesis. The title has provided an initial, if very general, clue, immediately followed in the first line by the reference to building an as yet unidentified "thing" and doing it "right there in the middle of the damn field." By the fourteenth line, we know that the "thing" to be built is "a damn boat," and only eight lines later we are informed that "it ain't no goddamn fishin [sic] boat he wants to put up neither in fact it's the biggest damn thing I ever heard of..." (636-7). The connection is made irrevocably obvious later in the story when the narrator tells his wife he has been to the scene and observed it is inhabited by Noah's family and "all kindsa damn animals and birds and things...a whole damn menagerie all clutterin and stinkin up the boat" (639). These major points are reinforced by subtler references to the Biblical tale, such as Noah, his wife, and their sons and their wives being the only humans on board, and the torrential rains which deluge the countryside for many days. Another significant detail is the "otherworldliness" of Noah himself, documented by his brother's comments about Noah being "lost in his fog" and "never do[ing] nothin in a normal way." Over and over the brother/narrator characterizes Noah as "loony" or "crazy," a perception which is reinforced by the narrator's wife's complaints about "that red-eyed brother of your wingin around like a damn cloud and not knowin what in the world he's doing," Noah's own wife's decision to "have no truck with him no more," and the neighbors" "shakin their heads and swearin under their breath and disgusted they got weaseled into the thing." The boatbuilder himself-never explicitly identified as Noah-fends off all questions and doubts by doggedly repeating that everything but getting the boat done simply "don't matter none." Ironically, the narrator expresses his surprise at his 
brother's unusual efficacy by pondering "God knows how he ever found out to build a damn boat." Clearly, the builder of the ark in this tale shares a great deal with the Biblical Noah.

Readers who make the Noah connection are thus likely to be sympathetic towards the boatbuilder, seeing his determination as evidence of his great faith and his refusal to include his brother and pregnant sister-in-law as a regrettable but unavoidable decision, laudable in its obedience to God's instructions. After all, he is, from that perspective, simply following orders. According to the Biblical story, God chose Noah as the only patriarch to survive because he was the only truly righteous man on earth at that time. Coover, however, challenges Christian beliefs and behavior through the novelty of the narrative perspective of the (presumedly Noah's) brother. From this perspective, Noah is far from heroic, not to mention Christian, in his behavior. He mistreats his wife, making her "sit out on a hillside for three whole days rain and everything because he said she'd see God and she didn't see nothin and in fact she like to die from hunger" (636) and vowing to drag her onto the boat if she refuses to go voluntarily. He exploits his younger brother mercilessly, imploring him to help "because he don't know how he can get it done in time otherwise," and knowing his brother has always done what he could to take care of him. The younger brother's wife reminds him that "he ain't never done nothing for you God knows," but her husband replies "I will of course I always would crazy as my brother is I've done little else since I was born" (636). Most troubling of all, of course, is "Noah's" refusal to help his brother once the flooding starts. The first time the narrator sees Noah on the ship, Noah "don't say nothin but he raises his hand kinds funny like and then puts it back on the rail" (639). The second time, the narrator desperately hollers at his brother, who "comes out and he looks down at where I am and he don't say nothin that bastard he just looks at me....and...right while I'm still talkin he turns around and he goes back in the boat and I can't hardly believe it me his brother" (640). The third (which has its own symbolic connotations) attempt is even more pathetic because the narrator gets no response at all: "I push up under the boat and I beat on it with my fists and scream at him and call him every name I can think up and I shout for his boys and for his wife and for anybody inside and nobody comes out "GODDAMN YOU'" (640). These scenes give rise to serious questions about religion, ethics, and social norms, all in terms of the relationship (both literal and metaphorical) between the two men. Is the boatbuilder to be praised for his obedience, or condemned for his selfishness? Is he to be pitied for the difficulty of his situation, or condemned for his heartlessness? Should he follow the letter of the law (saving only himself, his family, and the animals) or the spirit of the law (treating others as he would want them to treat him), when the law in question is none other than God's commandments? In the Bible, the great flood is God's solution for punishing a corrupt society, a method with mythic overtones of healing destruction and purification, but Coover's story forces the reader to revise religious assumptions about righteousness and merit.

The narrator's innovative perspective on this classic Biblical episode calls into question not only Christian ideals of obedience and brotherhood, but also cultural norms of family and morality. Contemporary western societies tend to give family relationships a primacy in direct proportion to its perceived role of fomenting the well-being of its individual members and the social group to which it belongs; blood ties are seen as immutable and fundamental. The family is perceived as a unit in which each member is responsible for contributing to the well-being of the others, particularly when dealing with the responsibilities of parents and older siblings 
toward younger children; elders are seen as having an obligation to protect and care for younger members of the family. In Coover's story, as discussed in the previous paragraph, the reverse proves to be true in several ways. The younger brother-a significant twenty years younger-is the one who takes care of his older brother, a task he perceives as being his since birth. The older brother not only fails to contribute to his sibling's well-being, but also actively excludes him from the ark and, therefore, from any hope of salvation. This becomes even more poignant and pointed when considerations of the narrator's very pregnant wife fail to change his brother's attitude or behavior.

The marital relationships of the two couples are used to reinforce the basic differences in the two brothers. The relationship of the older brother and his wife is characterized by "domestic quarrels," as reported by the narrator, while the younger brother's relationship to his wife is clearly a nurturing one. She does not like his neglecting their farm in order to help his brother, but she "packs [him] some sandwiches just the same and some sandwiches for [his] brother" (636), takes over his chores as much as she is able, and gives him backrubs when he gets home. Her husband's narration is sprinkled with frequent references to his concern for his wife's condition, and he is even willing to swallow his pride and ask his brother for shelter because "my house is fulla water and my wife she's about to have a kid and she's apt to get sick all wet and cold to the bone" (640). Most ironic of all is the episode when the younger brother uses leftover wood from the ark to make a fanciful cradle with little carved animals for the coming baby, and they tenderly celebrate their happy family with wine, laughter, and shared jokes, falling asleep in one another's arms. Their closeness, consideration, and acceptance of each other contrast sharply with the other brother's relationship with his wife, as well as with his brother. The reader cannot but wonder why this young, loving family is sacrificed, while the other family, complete with "his boys [who] ain't so bright neither," are chosen to rebuild the human race. The moral issues at stake here are reinforced by the fact that none of the adults in the story is identified by name, suggesting prototypes or even allegory. In fact, the only capitalized names used in the story are those of God and the future baby (identified as Nathanial or Anna, also Biblical names), and even here it must be noted that "God" is always used as part of a phrase (often an expletive), such as "by God" or "God what a mess" or "God knows." In other words, God is definitely a presence in this story, but not necessarily a benign one, distancing it still further from its Biblical counterpart. The generic identification of the main characters is a significant element in the polyvalence of the story's "meaning." However, at the same time that it lends an ambiguity which feeds the intertextuality of the text, it also tends to negate the reader's initial (and therefore strongest) frames for constructing meaning.

One of the most effective strategies Coover employs to thwart the temptation to process this story simply as a retelling of Noah and the Ark is the debunking of one of the strongest of short story conventions: the sense of closure. Lohafer and Clarey assign an entire section of their book Short Story Theory at a Crossroads to the issue of closure, carefully selecting representative essays to attest to the enduring significance of this aspect of short story theory as well as to the gamut of perspectives and positions on this issue. As Lohafer and Clarey affirm, traditionalists who follow Poe's lead see closure not only as essential, but also as the guiding structural principle of a short story, on the premise that "it was the function of art to enclose and interpret some portion of experience" (Lohafer 1989: 109), as well as both the "nature" and 
"formal duty" of short story to "click" at the end. Many contemporary critics and theorists, however, tend to substitute concerns for "totality" and "single effect," which respond to formalist aesthetics, with a preoccupation with cognitive patterns and perceptions more in line with what Frank Kermode has called "a sense of an ending." John Gerlach suggests five types of "closural signals" which function within short stories: "solution of the central problem [oldfashioned resolution], natural termination..., completion of antithesis..., manifestation of a moral [or simply emergence of a theme, in modern fiction], and encapsulation" (qtd. in Lohafer 1989: 110). Leitch argues that the "debunking" rhythm which characterizes U.S. short stories culminates precisely at the end of the story when, paradoxically, the conceptual challenges which have been launched remain unresolved. In his words, the "debunking story...displays as its point and purpose the process of unknowing" (Leitch 1989: 140), without positing alternative knowledge. Coover's "ending" (like his "beginning") does precisely that; although the narrator's wife has died and he is ruminating rather pessimistically about his own future, his narrative merely stops, rather than finishes. The story is truncated as arbitrarily as it was begun, which effectively forces the reader to reconsider not only immediate issues of "message" (justice and brotherhood) and plot development (has this story really "ended"?), but also much larger issues of interwoven life stories, multifaceted Mobius structures of intertexts, and essentially undifferentiated beginnings and endings. As its structure manifests, Coover's story begins, but not at the beginning, and stops, but does not end.

In "The Brother," Robert Coover steadily assaults readers' expectations and assumptions through a variety of techniques which share only their questioning nature and their united effect: to challenge intellectual complacency, academic pedantry, and philosophical and moral sophistry. In other words, Coover ingeniously "debunks" any facile constructions of meaning for this story, while simultaneously calling into question traditional criteria both for structuring and responding critically to short stories, a very daunting task and an equally admirable achievement. By conscientiously exploiting the immediate intertextuality of the content as a means to confront the readers' underlying premises, Coover himself intertwines short story conventions with vital innovation, making a significant contribution to the dynamics of short story poetics in the process.

\section{Works cited}

Barthes, Roland. 1977. Image-Music-Text. Trans. Stephen Heath. New York: Noonday.

Brown, Suzanne Hunter. 1989. "Discourse Analysis and the Short Story". In: Lohafer and Clarey (eds.), 217-48.

Coover, Robert. 1982. "The Brother". In: Current-Garcia and Patrick (eds.), 636-41.

Culler, Jonathan. 1980. “Literary Competence”. In: Tompkins (ed.), 101-18. 
Current-Garcia, Eugene and Walton R. Patrick (eds.). 1982. American Short Stories. Glenview, IL: Scott, Foresman.

Fish, Stanley. 1980. Is There a Text in This Class? Cambridge: Harvard UP.

Iser, Wolfgang. 1980. "The Reading Process: A Phenomenological Approach". In: Tompkins (ed.), 50-69.

Kristeva, Julia. 1986. "Word, Dialogue, and Novel”. In: Moi, 34-61.

Leitch, Thomas M. 1989. "The Debunking Rhythm of the American Short Story". In: Lohafer and Clarey (eds.), 130-47.

Lohafer, Susan and Jo Ellen Clarey (eds.). 1989. Short Story Theory at a Crossroads. Baton Rouge: LA State UP.

Moi, Toril (ed.). 1986. The Kristeva Reader. NY: Columbia UP.

Rohrberger, Mary. 1989. "Between Shadow and Act: Where Do We Go from Here?". In: Lohafer and Clarey (eds.), 32-45.

Scholes, Robert. 1989. Protocols of Reading. New Haven: Yale UP.

Tompkins, Jane (ed.). 1980. Reader-Response Criticism. Baltimore: Johns Hopkins UP.

Wright, Austin. 1989. "On Redefining the Short Story: The Genre Question". In: Lohafer and Clarey (eds.), 46-53. 